\title{
3 Research Square

\section{A Current Approach to Mean Temperature Trends and Relationships With Teleconnection Patterns in California (U.S.)}

Alejandro González Pérez ( $\sim$ agonzp07@gmail.com )

University of Leon

Ángel Penas Merino

University of Leon

Sara del Río González

University of Leon

Ramón Álvarez Estebán

University of Leon

\section{Research Article}

Keywords: Atmospheric circulations, California, Global warming, Teleconnection Patterns, Temperature Trends

Posted Date: January 21st, 2022

DOI: https://doi.org/10.21203/rs.3.rs-1217349/v1

License: (c) (1) This work is licensed under a Creative Commons Attribution 4.0 International License. Read Full License 


\section{Abstract}

The aim of this research is to expand our knowledge of space-time evolution of mean temperatures at a regional level, for the whole California (United States) over 40 years. This study analyses the relationship between mean temperatures and teleconnection patterns with most influence on the Californian Climate. 170 meteorological stations were used with an observation period that ranged from 1980 to 2019. In order to evaluate the presence or absence of trends, the non-parametric Mann-Kendall test was used. The slope was obtained with a modified Sen's slope method. The homogeneity of the data from the selected stations was verified. To find out the relationships between temperature and a wide range of teleconnection patterns in California was performed a correlation analysis using the partial non-parametric Spearman Test at a 95\% confidence level. Spatial analysis was achieved using Empirical Bayesian Kriging (EBK). During this period, the results show a positive and significant trend annually, monthly and seasonally. Both Pacific Decadal Oscillation (PDO) and West Pacific Oscillation (WPO) are related to temperatures in California State during the period studied.

\section{Introduction.}

Global warming is one of the current challenges that human beings have to face due to its negative effects on society, such as floods ${ }^{1}$, heat waves, fires and droughts ${ }^{2}$, which are becoming more and more serious over time. The impact produced on ecosystems and on human well-being and health are associated with an increase in average temperatures ${ }^{3-5}$. The most significant evidence of this Global warming is the increase in air temperature ${ }^{6}$. Global mean surface temperature has risen since the late 19th century ${ }^{7}$. Each of the last four decades has been successively warmer than any decade that preceded it since 1850. The first two decades of the 21st century (20012020) was 0.99 [0.84- 1.10$]^{\circ} \mathrm{C}$ higher than 1850-1990. Global surface temperature was 1.09 [0.95 to $1.20{ }^{\circ} \mathrm{C}$ higher in $2011-2020$ than $1850-1900$, with larger increases over land $\left.(1.59 \text { [1.34 to } 1.83]^{\circ} \mathrm{C}\right)^{8}$. It is practically certain that the minimum and maximum temperatures of the Earth's surface have increased on a global scale since 1950 . However, recent studies suggest that there are slight variations in the maximum and minimum temperatures and these can be easily altered by human activity and land uses at a regional level ${ }^{10}$.

Understanding the trends of climatic variables such as temperature is of great importance both theoretically and in an applied way. From a theoretical point of view, it helps to understand how it has been changing based on previous observations. Moreover, we can establish both the characteristics of this parameter and the trend and use it to project what will happen in the future. Climate is variable in time and space, so detecting a significant trend is a great challenge for researchers. To analyse climate data, it is useful to use conceptualizations (mathematical equations)

11 that reduce complexity such as the average temperature. To determine its linear trend, we examine the data values according to when they occurred in the past and then determine a line of fit through that data. The gradient of that line will give us the trend.

The calculation of trends in climatic parameters such as average temperature, maximum and minimum temperature has been the subject of a great deal of research in recent years (Cordero et al., 2011; del Río et al., 2011; del Río et al., 2013; Hansen et al., 2010; Ichijo and Ranta, 2016; Karmeshu, 2015; Lluch-Cota et al., 2013; Shrestha et al., 1999) and has been carried out in a wide variety of territories around the world. Most of the studies at this point have focused on large-sale temperature trends. However, it is necessary to carry out more research to focus on the change that occurs at a regional level using the above-mentioned parameters. In this way, researches carried out on decadal trends in average temperatures in various territories of the United States provided impressive results. In this regard, average temperatures across the US have increased from the 1950 s to the beginning of the century more than $0,5^{\circ} \mathrm{C}$. 
7,19-26. In order to study how global warming would affect life at a regional level, models and assessments of climate change often assume that the influence would be uniform. However, temperatures do not increase uniformly in space or time and few studies have focused on that peculiarity over California State ${ }^{12,27-29}$. The colder hours of the day (nights), the coldest times of the year (winter), and the colder parts of the world (high latitudes) tend to heat up faster. Although, and in contrast to this, in the State of California, temperatures have undergone great variations over the last 100 years, with greater warming being experienced in the southern desert territories ${ }^{12,30}$, where temperatures were regularly high, while in the northern territories the increase has taken place gradually. To be more precise, these temperature increases are uneven for the different regions of the centre and north of the State.

Several climatological research papers have suggested that much of current climate variability observed can be related to variability within a teleconnection pattern ${ }^{31}$. The term teleconnection pattern refers to a large-scale recurring pattern that persists over time with pressure and circulation anomalies that extend to wide geographic areas. In addition, sometimes these patterns can last for several consecutive years. There are some patterns of teleconnection that can directly or indirectly influence the monthly temperatures of a region of the planet such as the United States ${ }^{31-37}$, or act on a smaller spatial scale such as the State of California ${ }^{38-43}$. Teleconnection patterns that may influence the United States, including tropical pattern that could affect the southern territories, are Antarctic Oscillation (AAO), Arctic Oscillation (AO), North Atlantic Oscillation (NAO), Pacific-North American Pattern (PNA), Madden Julian Oscillation (MJO), West Pacific Oscillation (WPO) that it is West Pacific (WP), describe by both Barnston and Livezey and Wallace and Gutzler, and the Eastern Pacific (EPO) whereas in the State of California they are mainly El Niño along the Southern Oscillation (ENSO) ${ }^{44-46}$ and the Pacific Decadal Oscillation (PDO) ${ }^{28,47,48}$. Although, the effects of teleconnection patterns on California climate variables such as precipitation has been studied before, temperature change and its relationship to teleconnection patterns needs further investigation.

Previous studies have revealed that the climate over California is changing, but how important is the change? Does it occur in a homogeneous way throughout the territory? These are still unsettled questions. With this research it is our intention to help respond these enquiries. There is a lack of current data on temperature trends that account for extreme temperature events in California from 2013 to the present. As far as we know, never before has an investigation been carried out in which the monthly, seasonal and annual values of average temperature trends between the years 1980-2019 for the State of California have been analysed. Furthermore, the aim of this research is to expand our knowledge of space-time evolution of mean temperatures at a regional level, revealing, on the one hand, the trend and its statistical significance of the average temperatures for the whole State of California over the last 40 years (1980-2019) at a monthly, seasonal, and annual rate. On the other hand, this study analyses the relationship between mean temperatures and teleconnection patterns with the most influence on the Californian Climate.

This research is original and shows up-to-date results in average temperature trends in California on a monthly, seasonal and annual time scale. As we have seen in previous studies, they have focused on the correlations of some atmospheric teleconnection patterns with temperatures in short periods of time, for example during a year or in isolated seasonal periods such as in winter. This study shows the possible influence of up to nine different teleconnection patterns taken all together in consideration on the average temperature in California over 40 years.

Finally, the authors consider that the findings of this study will help those responsible for land management so that they can take appropriate measures in advance, in the face of Global warming, thus helping them to minimise the effects of this phenomenon. 


\section{Materials And Method. \\ 2.1 Study area.}

This study is carried out in the State of California, the third largest state in the United States, with an area of 423.955 $\mathrm{km}^{2}$. Its orography varies from $84.1 \mathrm{~m}$ below sea level in Death Valley to $4418.1 \mathrm{~m}$ above sea level on the peak of Mount Whitney ${ }^{49}$. California consists of two major series of mountain ranges: the Coastal Range, the Sierra Nevada, plus the southern tip of the Cascade Range, including Mount Lassen and Mount Shasta. Between these two axes lies the Greater Central Valley, whose Sacramento and San Joaquin river systems drain through Golden Gate (Fig. 1). California's climate is highly variable, and the area ranges from desert to subalpine environments (Pathak et al., 2018). Its complex topography and great latitudinal extension favour a wide variety of climates. Thus, its proximity to the Pacific coast is one of the determining factors in the climate of the state. A Mediterranean climate predominates throughout the state, except for the mountain area of Klamath where there is a temperate climate and the southeast in the Sonoran desert where we find a tropical climate ${ }^{27}$.

\subsection{Data.}

We chose a wide range of years for this study, a total of four decades (from 1980 to 2019). Three decades are recommended by the World Meteorological Organization (WMO). We took the temperature data from the climatic database of the meteorological stations available on the WRCC website ${ }^{50}$. Monthly average temperature $\left({ }^{\circ} \mathrm{C}\right)$ data were selected from 350 stations available for California State. 170 of them were finally used for the study (Fig. 1). The largest number of stations were chosen which covered the maximum surface of the study area ${ }^{51}$. The altitude values and geographic coordinates of each of the stations used were also added to the database to facilitate the representation of the results obtained on maps at a later date. For the statistical treatment of the data, the analysis of the homogeneity of the series was carried out. In this study it was determined by the Run test (Thom, 1966) with a confidence level of $99 \%$. This test is recommended by the World Meteorological Organization (WMO), because it does not require the analysed series to come from a normal sample and it has also been previously used by other climatic studies ${ }^{14,52}$.

\subsection{Trend analysis.}

In order to evaluate the presence or absence of trends we calculate it with the non-parametric Mann-Kendall test, once the homogeneity of the data from the selected stations was verified ${ }^{16,53,54}$. The Mann-Kendall test, referred to as the Kendall tau test, is one of the most widely accepted non-parametric tests for detecting trends in time series 51,55-57. The Sen slope estimator is a non-parametric procedure that estimates changes per unit of time in a series when there is a linear trend.

R package version 4.1.0 was used both to carry out the slope calculations, obtained with a modified Sen's slope method and the Mann-Kendall test ${ }^{58}$. All trend analysis was carried out at monthly, seasonal and annual temperature levels. In California, there are 4 seasons: Winter (December, January and February), spring (March, April, and May), summer (June, July, August) and autumn (September, October and November). From now on the months of these seasons will be named as DJF, MAM, JJA and SON respectively. California annual temperature was computed using Voronoi polygons weighting temperature stations by the area of each polygon ${ }^{59}$. 
In many regions and areas of the planet it is a challenge to conduct climatic analysis since there are not enough meteorological stations ${ }^{60}$, thus statistical interpolation of the values is necessary for a specific region. In order to carry out this interpolation, ArcGis 10.8 @ ${ }^{61}$ software was used and more specifically an Empirical Bayesian Kriging geoprocessing tool (EBK). It is a method of interpolation of geographic statistics where the standard errors of the prediction are more precise than in other kriging methods ${ }^{62-64}$. In addition, 17 average temperature trend contour maps were designed with ArcGis 10.8 (c) and statistically significant areas were also superimposed onto the contour maps.

\subsection{Atmospheric Teleconnection Patterns.}

Values of atmospheric circulation pattern indices were taken both from the Climate Prediction Center available on the NOAA National Climatic Data Center (NCDC) website (https://www.ncdc.noaa.gov/teleconnections/) similar to previous research ${ }^{12,37,48}$ and the Real-Time Multivariate Madden-Julian Oscillation (RMM) index were obtained from the Australian Bureau of Meteorology (http://www.bom.gov.au/climate/mjo/graphics /rmm.74toRealtime.txt). We have chosen each one of the teleconnection patterns that can influence climate in the United States and in the State of California, namely El Niño 3.4 (ENSO) and the Pacific Decadal Oscillation (PDO) ${ }^{43,65}$. Pattern indices for Antarctic Oscillation (AAO), Arctic Oscillation (AO), Madden-Julian Oscillation (MJO), North Atlantic Oscillation (NAO), PacificNorth American Pattern (PNA), West Pacific Oscillation (WPO) and East Pacific Oscillation (EPO) were also taken in consideration.

To find out the relationships between temperature and teleconnection patterns in California a correlation analysis using the partial non-parametric Spearman Test was performed at a 95\% confidence level ${ }^{58}$. This method (the Spearman test) assigns less significance to outliers and It is a more robust and resistant alternative for measuring correlation (linear or nonlinear). In addition, this test eliminate the effect that the time variable can exert on the temperature and telepattern variables, in order to avoid fictitious relationships ${ }^{66}$. Finally, all the correlation results and their statistical significance are represented in monthly maps.

\section{Results And Discussion. 3.1 Temperature trends.}

The results of the global analysis of temperature in California (Table 1) show that positive trend exist in the whole State. The highest value is found in November $\left(+0.04{ }^{\circ} \mathrm{C}\right.$ year $\left.{ }^{1}\right)$ and it is statistically significant, the same arises with July, August, summer and autumn where the trend reaches $+0.03^{\circ} \mathrm{C}$ per year. It is noteworthy that January has shown the same trend $\left(+1.6^{\circ} \mathrm{C}\right)$ over the period studied such as November but is not statistically significant. This results show similarities with other researchers conducted in the State. They have shown that regionally positive temperature trends exist in California but for the northeast region that was proved to be negative ${ }^{12,28}$. 
Table 1

Mean temperature trends $\left({ }^{\circ} \mathrm{C} /\right.$ year) in the State of California. ${ }^{*}$ Statistical significance (pvalue) at $\mathrm{a}=0.05$.

\begin{tabular}{|llllllllll|}
\hline & January & February & March & April & May & June & July & August & September \\
\hline Slope & 0.04 & 0 & 0.02 & 0.02 & 0.01 & 0.03 & 0.03 & 0.03 & 0.01 \\
\hline pvalue & 0.06 & 0.87 & 0.37 & 0.53 & 0.44 & 0.07 & $0.03^{*}$ & $0.01^{*}$ & 0.23 \\
\hline & October & November & December & Winter & Spring & Summer & Autumn & Annual & \\
\hline Slope & 0.01 & 0.04 & 0.02 & 0.02 & 0.01 & 0.03 & 0.03 & 0.01 & \\
\hline pvalue & 0.58 & $0.02^{\star}$ & 0.25 & 0.25 & 0.38 & $0.02^{\star}$ & $0.02^{*}$ & 0.13 & \\
\hline
\end{tabular}

The results of analysing temperature trends (positive and negative) at monthly, seasonal and annual average temperature from 1980 to 2019 in the State of California as well as its statistical significance at a confidence level of $95 \%$ are shown in figure 2.

Positive trends were found each month in more than $60 \%$ of the stations. The exception to this is February where $57 \%$ of the stations show negative trends. No statistical significance was found for negative trends (Fig. 2). Figure 2 revealed that January, June, July, August and November are the months that have shown the highest values of positive statistical significance. Although several stations have shown no statistical significance, it is notable that when it is positive, there are significant trends in nearly half of the stations studied (40\%).

According to the monthly results in January the spatial distribution of positive trends was found all over the State, close to $80 \%$ of the stations as can be seen in figure 2 . This is especially high $\left(+2.25{ }^{\circ} \mathrm{C}\right.$ increase over the period studied) in the Sacramento and San Joaquin Valley (30\% of the stations are statistically significant).

Autumn is the season that shows the highest percentage of weather stations with positive average temperature trends $(90 \%)$ and there are $35 \%$ of weather stations with statistically significant positive trends in contrast to the lowest percentage that is shown in spring $(72 \%)$ and only $4 \%$ show statistical significance. November shows the highest percentage of stations with positive trends ( $96 \%)$, as well as the highest value (38\%) of statistically significant stations.

This result agrees with other research ${ }^{67}$ that said that a significant rise in annual mean temperatures in this area is up to $+0.07^{\circ} \mathrm{C}$ per decade ${ }^{1}$. This rapid warming valley seems to be caused by the development of irrigated agriculture ${ }^{68}$ in contrast to the slight increase they had found in Sierra Nevada. Irrigated agriculture increases the minimum temperature $\left(T_{\min }\right)$ values in these areas, and seems not to have an effect on maximum temperatures $\left(T_{\max }\right)$, which explains the increase in mean temperatures. These findings in Sacramento and San Joaquin Valley have been proved in this research to be similar in June, August, November and December up to an increase of +0.05 ${ }^{\circ} \mathrm{C}$ year ${ }^{1}$. The San Joaquin and Sacramento rivers originate in the Sierra Nevada and the mountainous regions in the north run through this region. The confluence of the rivers occurs in the Sacramento-San Joaquin Delta. Most of the water from these rivers comes from snowmelt, and the increase in temperature trends in the winter season (DJF) would mean acceleration in the snow melting season. This results agree with other research conducted in other mountain systems ${ }^{69}$. In those three months, over the period studied, high positive trends $\left(+0.8-1.2^{\circ} \mathrm{C}\right)$ have been found all over California, nearly $90 \%$ of the stations. That rapid melt can cause difficulties in the maintenance of fresh water in agriculture and for human consumption as suggested by some researchers ${ }^{5,70-72}$. The Central Valley can be more vulnerable to warming-driven drought if reductions in water supply cause reductions in irrigation ${ }^{73}$. The prediction map for February revealed a lack of clear trends due to the fact that there is no distinct direction in positive 
or negative temperature trends. These findings support the results shown on the NOAA website (https://www.ncdc.noaa.gov/temp-and-precip/us-trends/), that said, strong trends are not shown, this is because the period studied is defined by warm Februarys in the 90's and cold ones in 00's in California State.

We can see great similarities in both March and April temperature trends. During these months, the Northeast of California tends to show slightly negative temperature trends in $30 \%$ of the stations $\left(-0.4^{\circ} \mathrm{C}\right.$ from 1980 to 2019$)$, while in South Sierra Nevada, the Mojave Desert, Los Angeles, Imperial Valley, San Gabriel and San Bernardino Mountain, the average temperature had gone up $+1.6^{\circ} \mathrm{C}$ during the period studied. The results in May for California are different from the rest of the year, because in the southern coastal region and in San Francisco Bay a negative trend appears $\left(-0.01^{\circ} \mathrm{C}_{\text {year }}{ }^{-1}\right)$, and this could be related to the penetration of coastal marine fog ${ }^{74}$ because on the coast of California, coastal marine fog varies seasonally. ${ }^{75}$. That is important due to the moisture content of air near the surface making this a regional phenomenon with strong local patterns ${ }^{76}$. This cooling effect that we have mentioned before has been explained by previous investigation ${ }^{74}$, but in this research it seems to have a lesser effect, instead of being negative, trends are close to zero, similar to what has been mentioned in other research ${ }^{77}$.

During June, July and August, the temperature has risen all over the State $\left(+0.065^{\circ} \mathrm{C}\right.$ year $\left.{ }^{1}\right)$, being more statistically significant in July and August (30\% of the stations analysed). Map prediction confirmed that these months show a high statistical significance in the North of the State, Mt. Shasta, part of the Cascade Ranges and Lake Tahoe, and a huge area of Death Valley and the Mojave Desert. These results are related to those which confirm increases in trends of heat waves in south California ${ }^{78}$, becoming more and more frequent in urban environments than in more rural surroundings, the result being a higher risk of heat-related births ${ }^{79}$ and deaths as well as an increase in wildfires. September has great similarities to those months but with less statistical significance.

Nevertheless, in October there is a negative trend $\left(-0.01^{\circ} \mathrm{C}\right.$ year $\left.{ }^{1}\right)$ without statistical significance in the north with more coastal areas, covering Eureka city up to Shelter Cove. This result is in line with other research ${ }^{12}$. In the case of November, the western coastal zone is cloudy and mild, northern areas are rather cooler than the southern, reaching an average temperature of $17^{\circ} \mathrm{C}$ in some years. The results for this month show both positive trends $\left(+0.05^{\circ} \mathrm{C}\right.$ year $\left.{ }^{1}\right)$ and statistical significance in Sacramento and San Joaquin Valley, Sierra Nevada, Los Angeles, San Francisco Bay, Yosemite and Southern Lake Tahoe, as was pointed out by Cordero et al. (2011). They reported that from 1970-2006 the largest warming in $\mathrm{T}_{\max }$ (from $+0.06{ }^{\circ} \mathrm{C}$ decade ${ }^{1}$ to $+0.26{ }^{\circ} \mathrm{C}$ decade ${ }^{1}$ ) occurred in these locations. Last but not least, December shows a positive temperature trend in most of California with the exception of the northwest, where it has been noted that there has been a negative trend with a decrease of $0.62^{\circ} \mathrm{C}$ during the period studied, although it is not statistically significant. In addition, the territories of Sacramento and San Joaquin Valley show the highest value of positive trends $\left(+0.032^{\circ} \mathrm{C}\right.$ year $\left.{ }^{1}\right)$ and it is statistically significant. As we have previously pointed out, this is a rising concern, due to the fact that snowmelt increases in mountain areas probably causing shortage in water supply in the months to come.

If we focus on seasonal trends, it is possible to observe a different seasonal pattern between results. It is especially striking that both summer $\left(+0.03{ }^{\circ} \mathrm{C}\right.$ year $\left.{ }^{1}\right)$ and autumn $\left(+0.02{ }^{\circ} \mathrm{C}\right.$ year $\left.{ }^{1}\right)$ have shown statistically significant positive trends. The area with statistical significance spread over the Mojave Desert and Death Valley, supports the idea mentioned before that the south of California is warming more than the north of the State. In summer it has been observed that the values of the trend increase towards the interior of the State as we move away from the coast, this is in places where the values in the trend are very low and do not present statistical significance. These results agree with those presented by previous investigations that claim there is a cooling trend over coastal Californian regions in 
summer. This drop in average temperatures is due to a wide range of factors such as, irrigation, coastal upwelling or cloud cover. The increase in temperatures over inland areas increases sea-breeze flow activity ${ }^{28,74}$ lowering the temperatures in coastal zones of the State. The spatial distribution of winter trends permits us to discriminate between two distinct areas: one formed by the territories of the Klamath Mountains and the other by the north of the Cascade Range, where we find a negative trend in temperatures that are not statistically significant during the period studied. The rest of the territory in this season presents a positive temperature trend of $+0.02{ }^{\circ} \mathrm{C}$ year ${ }^{1}$, it is noteworthy that this value is statistically significant in Sacramento Valley, San Joaquin Valley and in the south of Sierra Nevada. It was observed that in spring the value of the trend shows clear warming throughout the territory but with slight statistical significance.

Finally, the spatial distribution of annual trends represented in figure 3 reflects clear warming in the territory, $+0.6{ }^{\circ} \mathrm{C}$ from 1980 to 2019, except for the northern area, in the Klamath Mountains where there is no clear trend in the average temperature, which has been indicated previously by He and Gautam (2016). It can also be observed that this positive trend in the territory is especially important in the south of the State, there is statistical significance in the southeast of Sierra Nevada, coinciding with the Valley of Death and much of the Mojave Desert. These results coincide with those proposed by Cordero et al. (2011) during 1918-2006 for the maximum and minimum temperature trends since both parameters show a significant rising in the southern part of the State. The whole State getting warmer has concerning implications, such as the snow on the mountainous systems of California melting earlier in winter-spring, which is likely to decrease the water supply even further next season ${ }^{71,80}$. In addition, more heat produces more evaporation and so irrigation farmland would need more water, increasing the lack of fresh water even more. All in all, over the period of study as can be seen in figure 2, no negative statistical significance was found in California. According to some studies, the increase in temperature is greater in areas of higher agricultural activity, such as the east of the Rocky Mountains, due to the fact that it helps to increase the surface heat capacity and therefore the temperature ${ }^{81}$. Several investigations suggest that these differences in the increase in temperature are affected by several factors; some of them are anthropic activity, land uses and the emission of greenhouse gases 10,82. Greenhouse gases appear to be related to the increase in average temperatures and the impact derived from this increase ${ }^{71}$. Research on the possible causes of the increase in temperature in the State of California, shows that the existing changes in atmospheric teleconnection patterns have significantly altered the extreme temperature events that take place in said region ${ }^{29}$. There is a concrete example in the North Pacific Ocean where surface temperatures correlate highly with Californian temperatures ${ }^{83}$. Finally, a great deal of climatological research suggests that temperature variability can be related to variability within the atmospheric flow ${ }^{31}$.

\subsection{Teleconnection patterns.}

This section shows the results of the spatial and statistical analysis between temperatures and up to nine teleconnection patterns. Table 2 shows the percentage of the stations with positive, negative or no statistical correlation ( $\left.p_{\text {value }}<0.05\right)$ between the teleconnection patterns and the mean temperature in California. The results of the correlations of atmospheric teleconnection patterns and temperatures are presented in the same way as previous investigations have done with another pattern or variable $13,14,51,84,85$. 
Table 2

Percentages of weather stations with statistically significant positive (+) or negative $(-)$ correlations, between teleconnection patterns and average temperatures $(a=0.05)$.

\begin{tabular}{|c|c|c|c|c|c|c|c|c|c|c|c|c|c|}
\hline & & Jan & Feb & Mar & Apr & May & Jun & Jul & Aug & Sep & Oct & Nov & Dec \\
\hline \multirow[t]{2}{*}{ PDO } & + & 9.3 & 52.2 & 72.1 & 8.1 & 19.2 & 30.2 & 15.2 & 9.3 & 33.1 & 37.2 & 18.6 & 27.3 \\
\hline & - & & 0.6 & & & & & 1.2 & & & 0.6 & & 0.6 \\
\hline \multirow[t]{2}{*}{ PNA } & + & 20.3 & 82.0 & 7.0 & & & 1.2 & 4.7 & 1.2 & & 37.2 & 18.0 & 15.1 \\
\hline & - & & & & 9.3 & & 29.1 & & 27.3 & 0.6 & & & \\
\hline \multirow[t]{2}{*}{ WPO } & + & & & & & 0.6 & & 0.6 & & & & 0.6 & \\
\hline & - & 42.4 & 90.7 & 95.9 & 92.4 & 35.5 & 8.1 & 5.8 & 4.1 & 8.1 & & 14.5 & 55.2 \\
\hline \multirow[t]{2}{*}{ EPO } & + & 52.3 & 7.6 & 2.9 & 77.3 & 12.2 & 0.6 & 1.2 & & 1.7 & 30.2 & 57.0 & No data \\
\hline & - & & & & 0.6 & & & & 2.3 & & & & No data \\
\hline \multirow[t]{2}{*}{ NAO } & + & 2.3 & 11.0 & 40.7 & 88.4 & 56.4 & 8.7 & 48.3 & 8.7 & & 1.2 & & \\
\hline & - & & & & & & & & & & & 9.3 & 1.2 \\
\hline \multirow[t]{2}{*}{ ENSO } & + & 1.2 & 14.0 & 15.1 & 1.2 & 2.9 & 0 & 0.6 & 0.6 & 4.7 & 0.6 & 0.6 & \\
\hline & - & & & & 0.6 & & & 7.0 & & & & 1.2 & 4.7 \\
\hline \multirow[t]{2}{*}{$\mathrm{AO}$} & + & & & 18.6 & & 26.7 & 41.3 & 20.9 & 11.0 & & & & \\
\hline & - & 6.4 & & & 0.6 & & & & & 0.6 & & 1.7 & 63.4 \\
\hline \multirow[t]{2}{*}{ AAO } & + & 3.5 & & & & 0 & 9.9 & & 3.5 & & & & \\
\hline & - & & 1.7 & & 35.3 & & & & & 0.6 & & & \\
\hline \multirow[t]{2}{*}{ RMM1 } & + & 7.0 & & & & & 1.7 & 2.3 & & 4.7 & 0.6 & & \\
\hline & - & & & 9.3 & 0.6 & 1.2 & 0.6 & 1.2 & 0.6 & & & & 2.9 \\
\hline \multirow[t]{2}{*}{ RMM2 } & + & 19.8 & & & & 2.3 & & 9.3 & & & & 41.3 & \\
\hline & - & 0.6 & & & & & 2.3 & & & & 2.9 & & \\
\hline
\end{tabular}

Temperatures in February, March, April and May are those that correlate most with the majority of the teleconnection patterns studied in the State of California.

Firstly, PDO in figure 4 shows that this pattern has a constant positive correlation throughout the year. This pattern, as this figure reveals, might have more influence on the average temperature on California's coastal areas such as San Francisco, Monterey Bay, Los Angeles and San Diego. We can observe in the maps that the stations with the strongest correlation are found along the coast as previous studies have brought to the fore ${ }^{12,28}$. The results of this are remarkable, particularly in May when $19.2 \%$ of stations were statistically significant, then June (30\%), September (33\%) and October (38\%). In March, when this teleconnection pattern had the highest percentage (72\%) of statistically significant stations, there was no difference between coastal and interior locations in the State. What it is remarkable about PDO is that the majority of the stations have shown significant positive correlation as can be seen 
in Table 2. This allows us to say that PDO is probably related to increases in average temperatures all over California in the period studied.

According to our results of the PNA pattern in figure 5, appears to be a strong correlation between average temperatures in February. In this month $82 \%$ of the stations all over California show the highest statistically significant correlation. During the months of June and October this pattern has some influence throughout the territory studied (30-36\% of meteorological stations).

In contrast, WPO has the highest percentage of the stations with statistically significant negative correlation with average temperatures. From December to April, negative correlation is observed in the area studied. These values are especially high throughout the territory, influencing $95.9 \%$ of the meteorological stations studied during the month of March and $42.4 \%$ during January. Although in this pattern, as we have previously commented, a spatial area of influence is not observed. We have to take into account that WPO is a temporary pattern and this could explain why it mainly affects the temperatures of winter ${ }^{38}$ and spring months in the State of California (Fig. 6, Table 2).

In addition, PDO and PNA are the two teleconnection patterns that present a high percentage of significant positive correlation while WPO has the highest negative correlation. These results bear striking similarities with previous investigations undertaken in California in other years $28,31,86$.

If we consider the results regarding the EPO teleconnection pattern (Fig. 7), we can state that it is the one that shows a significant positive correlation in November (57.0\%) along with PNA and PDO, however, the latter to a lesser extent. In December, the EPO pattern had no data because there were no values available for the period studied on the data sheet of the Climate Prediction Centre (CPC, NOAA). Searching for alternative values for this pattern in December was not considered in order not to mix diverse information sources. This pattern shows especially high values of positive correlation in April, where $77.9 \%$ of the temperature in the stations studied seem to be affected by EPO.

Moving on to NAO correlation results (Fig. 8), there are, in both March (40.7\%) and April (88.4\%), average temperatures that have significant positive correlations to this teleconnection pattern. In addition, the result for May is remarkable as this pattern affects the average temperature in up to $56.4 \%$ of the California stations studied. This is supported by another recent investigation where a substantial link between NAO and surface air temperatures over California during the March-June period was found ${ }^{87}$. Lastly, we can point out that NAO might have an effect on temperatures for five months, from March to July, throughout California. On the contrary, low significant correlation has been found for ENSO 3.4, and when there is some correlation (February and March), it is linked to the coastal stations (Fig. 9). These results were expected due to the fact that other research highlights the slight correlation with temperature ${ }^{12,88}$.

Contrary to what previous researchers have mentioned, AO (Fig. A1) shows a positive correlation and it is statistically significant in the months of March (18.6\%), May (26.7\%), June (41.3\%), July (20.9\%), and December (63.4\%) (Table 2). It is important to note that AAO is the pattern that seems to affect average temperatures the least in California (Fig. A2).

The Madden-Julian Oscillation (MJO) is both a global-scale complex teleconnection pattern of the tropical atmosphere and the dominant mode of interseasonal tropical variability ${ }^{89}$. One commonly used index for defining MJO is the real-time multivariate index RMM. The two principal components RMM1, RMM2 have been shown to be useful indices of the MJO and related variability ${ }^{90}$. Firstly, MJO is a two-dimensional phase space defined by RMM1 and RMM2. The union of these two gives as a result 8 equatorial phases of this teleconnection pattern. In the light of

Page $10 / 26$ 
the results of the correlation of these indexes with average temperature in California, January and November are the months that show the highest positive correlation. To be more precisely, RMM1 (Fig. 10) seems to haven't got any relation with temperatures over the period studied in California. In contrast, RMM2 (Fig. 11) shows highest value of correlation in November $41.3 \%$ and January $19.8 \%$ of the meteorological stations. One of the reasons of this results that are consistent with other research, could be that RMM1 describes the situation when a MJO produces an enhanced convection at the Maritime Continent while RMM2 has enhanced convection over the Pacific Ocean 90,91 closer to California State. In addition it is remarkable that the correlated stations with temperatures, in June, are located mainly both in coastal areas of San Francisco, Santa Barbara and Los Angeles and mountainous areas of Auburn, Oroville and Susanville. Dasgupta et al. (2020) found that the occurrences of MJO activity at RMM phase locations 4, 5 and 6 during boreal winter are related to the PDO index, particularly in the negative phases. The phases 6-7 of MJO are related to the convective anomaly in western Pacific that affects the weather in the United States, where warm anomalies were found particularly in mid latitude temperature and probably related to PNA ${ }^{89}$.

\section{Conclusions.}

In this research we have highlighted the current results of space-time scale evolution for mean temperature trends at a regional level and its statistical significance on a monthly, seasonal and annual basis during the period 1980-2019 for the State of California. In addition, this study has analysed the relationship between mean temperatures and with up to nine teleconnection patterns that may have the most influence on the Californian climate. It is the first time that EPO, AAO and WPO have been studied in relation to California State in particular, from 1980 to 2019. Nevertheless, the Western Pacific Oscillation has been studied in combination with the North Pacific Oscillation in North America 38 .

Finally, in the light of the results some important findings of this research are stated as follows:

- There is a marked annual increase in mean temperatures of $+0.6^{\circ} \mathrm{C}$ (average) from 1980 to 2019 in California. The whole State show a positive trend $+0.1^{\circ} \mathrm{C}$ per year. In addition, during that period, southern California is the region that has shown the highest statistically significant increase $\left(+0.7^{\circ} \mathrm{C}\right)$. This supports the previous idea that southern California is getting warmer than northern California.

- It has been shown that on a seasonal scale temperature increased significantly, during autumn and summer $\left(+2.40^{\circ} \mathrm{C}\right.$ and $+1.40^{\circ} \mathrm{C}$ respectively) from 1980 to 2019 . In this regard these are the seasons that achieve the highest statistical significance (36\% of stations) of positive trends.

- The highest increases on a monthly scale are found in: January, $+2.56^{\circ} \mathrm{C}$; June, July, and November with an increase of $+2.0^{\circ} \mathrm{C}$; in December up to $+1.30^{\circ} \mathrm{C}$ during the period studied. The months that have shown the highest statistical significance (in 20-38\% of stations) are January, June, July, August and November.

- The coastal cooling effect gives a mean temperature trend around zero as opposed to the results of previous research conducted in different time periods.

- It is possible that Pacific Decadal Oscillation (PDO), could have an important influence on average temperatures in California State during the period studied, particularly on coastal areas such as Los Angeles, San Francisco and Monterey. West Pacific Oscillation (WPO) has shown the highest statistically significant negative correlation from December to April. PDO, WPO, NAO, PNA and EPO are the teleconnection patterns that have shown the highest correlation from February to May and have explanatory potential in mean temperature over those months. 
- On the contrary, Antarctic Oscillation (AAO) and Arctic Oscillation patterns (AO) are unlikely to show any influence on average temperature trends in California.

- The Madden-Julian Oscillation, (RMM2) could play a role in January and November temperatures in the State, due to the fact that in the latter, $41.3 \%$ of stations have shown positive correlation.

- There is a great variability in the behaviour of the teleconnection patterns in the period studied.

Further investigations on teleconnection patterns and climate variables are essential to establish cause-effect relationships that help us to predict future changes in average temperatures. Knowledge of atmospheric teleconnections provides us with the opportunity to assess interconnection on a planetary scale. Last but not least, this work delves into the up-to-date knowledge of temperature trends in California and also shows their possible relationships with up to nine atmospheric teleconnection patterns. This research could help politicians to make justified decisions. Knowing the temperature trends in the state of California and the influence of teleconnection patterns on them, the policies could mitigate the possible effects caused by global warming.

\section{Declarations}

\section{Acknowledgement}

This work was supported by the European Regional Development Fund (ERDF) and Junta de Castilla y León (JCyL) to the first author include in a Fellowship Scheme for Doctoral Training Program: Orden de 12 de diciembre de 2019 de la Consejería de Educación (extracto publicado en el B. O.C. y L. n. ${ }^{\circ}$ 245, de 23 de diciembre. BDNS (Identifi.): 487971. I would like to thank Ruth J.R. Winter for her advice on correct English.

\section{Funding.}

This work was supported by the European Regional Development Fund (ERDF) and Junta de Castilla y León (JCyL) to the first author include in a Fellowship Scheme for Doctoral Training Program: Orden de 12 de diciembre de 2019 de la Consejería de Educación (extracto publicado en el B.O.C. y L. n. ${ }^{\circ}$ 245, de 23 de diciembre. BDNS (Identifi.): 487971.

\section{Competing Interests.}

The authors have no relevant financial or non-financial interests to disclose.

\section{Data Availability.}

The datasets generated and analysed during the current study are not publicly available due to the fact that $\mathrm{R}$ package are waiting to be published but original data source can be consulted in https://wrcc.dri.edu/ and are available from the corresponding author on reasonable request.

\section{Author contributions}

Ángel Penas and Sara del Río contributed to the study conception and design. Material preparation, data collection and analysis were performed by Ramón Álvarez Esteban. The first draft of the manuscript was written by Alejandro González Pérez and all authors commented on previous versions of the manuscript. All authors read and approved the final manuscript. 


\section{Ethical approval and responsibilities of Authors}

All authors in this research are aware of the submission and declare that:

- The manuscript is not submitted to any other journal for simultaneous consideration.

- The submitted work is original and has not been published elsewhere in any form or language.

- Results of this research are presented clearly, honestly, and without fabrication, falsification or inappropriate data manipulation.

- All authors agreed with the content and that all give explicit consent to submission and publication.

- This work does not include research including humans or animals.

\section{References}

1. Varlas, G. et al. A multi-platform hydrometeorological analysis of the flash flood event of 15 November 2017 in Attica, Greece. Remote Sens. 11, (2019).

2. Vicente-Serrano, S. M., Beguería, S. \& López-Moreno, J. I. A multiscalar drought index sensitive to global warming: The standardized precipitation evapotranspiration index. J. Clim. 23, 1696-1718 (2010).

3. Madsen, T. \& Fidgor, E. When it Rains, It Pours: Global Warming and the Rising Frequency of Extreme Precipitation in the US. Environ. Am. Res. Policy Cent. (2007). doi:10.1177/01461672992512010

4. MunichRe. North America most affected by increase in weather-related natural catastrophes. Press Release (2012).

5. Trenberth, K. E. The Impact of Climate Change and Variability on Heavy Precipitation, Floods, and Droughts. in Encyclopedia of Hydrological Sciences (2008). doi:10.1002/0470848944.hsa211

6. Pumo, D. \& Noto, L. V. Exploring the linkage between dew point temperature and precipitation extremes: A multitime-scale analysis on a semi-arid Mediterranean region. Atmos. Res. 254, 105508 (2021).

7. Hansen, J., Ruedy, R., Sato, M. \& Lo, K. Global surface temperature change. Rev. Geophys. 48, (2010).

8. Masson-Delmotte, V.. et al. Climate Change 2021: The Physical Science Basis. Contribution of Working Group I to the SixthAssessment Report of the Intergovernmental Panel on Climate Change. IPCC (2021).

9. Hartmann, D. L., Tank, A. M. G. K. \& Rusticucci, M. IPCC Fifth Assessment Report, Climate Change 2013: The Physical Science Basis. IPCC AR5, 31-39 (2013).

10. Lobell, D. B. \& Bonfils, C. The effect of irrigation on regional temperatures: A spatial and temporal analysis of trends in California, 1934-2002. J. Clim. 21, 2063-2071 (2008).

11. Mudelsee, M. Trend analysis of climate time series: A review of methods. Earth-Science Reviews 190, 310-322 (2019).

12. Cordero, E. C., Kessomkiat, W., Abatzoglou, J. \& Mauget, S. A. The identification of distinct patterns in California temperature trends. Clim. Change (2011). doi:10.1007/s10584-011-0023-y

13. del Río, S., Herrero, L., Pinto-Gomes, C. \& Penas, A. Spatial analysis of mean temperature trends in Spain over the period 1961-2006. Glob. Planet. Change (2011). doi:10.1016/j.gloplacha.2011.05.012

14. Del Río, S. et al. Recent mean temperature trends in Pakistan and links with teleconnection patterns. Int. J. Climatol. 33, 277-290 (2013).

15. Ichijo, A. \& Ranta, R. Summary for Policymakers. Climate Change 2013 - The Physical Science Basis (2016). doi:10.1017/CBO9781107415324.004

Page $13 / 26$ 
16. Karmeshu, N. Trend Detection in Annual Temperature \& Precipitation using the Mann Kendall Test - A Case Study to Assess Climate Change on Select States in the Northeastern United States. Univ. Pennsy/vania (2015).

17. Lluch-Cota, S. E. et al. Recent trends in sea surface temperature off Mexico. Atmosfera 26, 537-546 (2013).

18. Shrestha, A. B., Wake, C. P., Mayewski, P. A. \& Dibb, J. E. Maximum Temperature Trends in the Himalaya and lts Vicinity: An Analysis Based on Temperature Records from Nepal for the Period 1971-94. (1999).

19. DeGaetano, A. T. \& Allen, R. J. Trends in Twentieth-Century Temperature Extremes across the United States. J. Clim. 15, 3188-3205 (2002).

20. Martinez, C. J., Maleski, J. J. \& Miller, M. F. Trends in precipitation and temperature in Florida, USA. J. Hydrol. 452-453, 259-281 (2012).

21. Davey, C. A. \& Pielke, R. A. Microclimate exposures of surface-based weather stations. Bull. Am. Meteorol. Soc. 86, 497-504 (2005).

22. Hamlet, A. F., Mote, P. W., Clark, M. P. \& Lettenmaier, D. P. Effects of temperature and precipitation variability on snowpack trends in the Western United States. J. Clim. 18, 4545-4561 (2005).

23. Dracup, J. A., Lee, K. S. \& Paulson, E. G. On the definition of droughts. Water Resour. Res. (1980). doi:10.1029/WR016i002p00297

24. Lee, C. C. \& Sheridan, S. C. Trends in weather type frequencies across North America. npj Clim. Atmos. Sci. 1, 41 (2018).

25. Powell, E. J. \& Keim, B. D. Trends in daily temperature and precipitation extremes for the southeastern United States: 1948-2012. J. Clim. 28, (2015).

26. Vanos, J. K., Kalkstein, L. S. \& Sanford, T. J. Detecting synoptic warming trends across the US Midwest and implications to human health and heat-related mortality. Int. J. Climatol. 35, (2015).

27. Killam, D. et al. California Getting Wetter to the North, Drier to the South: Natural Variability or Climate Change? Climate (2014). doi:10.3390/cli2030168

28. LaDochy, S., Medina, R. \& Patzert, W. Recent California climate variability: Spatial and temporal patterns in temperature trends. Clim. Res. (2007). doi:10.3354/cr033159

29. Swain, D. L., Horton, D. E., Singh, D. \& Diffenbaugh, N. S. Trends in atmospheric patterns conducive to seasonal precipitation and temperature extremes in California. Sci. Adv. (2016). doi:10.1126/sciadv.1501344

30. Reed, D. D. Historical Temperature Trends in Los Angeles County, California. (2015).

31. Sheridan, S. C. North American weather-type frequency and teleconnection indices. Int. J. Climatol. 23, 27-45 (2003).

32. Daniel J. Leathers, B. Y., and M. A. P. [15200442 - Journal of Climate] The Pacific_North American Teleconnection Pattern and United States Climate. Part I_ Regional Temperature and Precipitation Associations. J. Clim. (1991). doi:https://doi.org/10.1175/1520-0442(1991)004<0517:TPATPA>2.0.C0;2

33. Franzke, C., Feldstein, S. B. \& Lee, S. Synoptic analysis of the Pacific-North American teleconnection pattern. $Q$. J. R. Meteorol. Soc. 137, 329-346 (2011).

34. Mamalakis, A., Yu, J. Y., Randerson, J. T., Aghakouchak, A. \& Foufoula-Georgiou, E. A new interhemispheric teleconnection increases predictability of winter precipitation in southwestern US. Nat. Commun. 9, 1-10 (2018).

35. Song, J., Li, C., Zhou, W. \& Pan, J. The linkage between the Pacific-North American teleconnection pattern and the North Atlantic Oscillation. in Advances in Atmospheric Sciences 26, 229-239 (2009).

36. Zhou, W., Yang, D., Xie, S. P. \& Ma, J. Amplified Madden-Julian oscillation impacts in the Pacific-North America region. Nat. Clim. Chang. 10, (2020). 
37. Yu, B., Lin, H. \& Soulard, N. A Comparison of North American Surface Temperature and Temperature Extreme Anomalies in Association with Various Atmospheric Teleconnection Patterns. Atmosphere (Basel). 10, 172 (2019).

38. Baxter, S. \& Nigam, S. Key role of the North Pacific oscillation-West Pacific pattern in generating the extreme 2013/14 North American Winter. J. Clim. 28, 8109-8117 (2015).

39. Macdonald, G. M. et al. Prolonged California aridity linked to climate warming and Pacific sea surface temperature. Scientific Reports 6, 1-8 (2016).

40. Schulte, J. Continuum-based teleconnection indices of United States wintertime temperature variability. Int. J. Climatol. 41, E3122-E3141 (2021).

41. Schwing, F. B. et al. Climate change, teleconnection patterns, and regional processes forcing marine populations in the Pacific. J. Mar. Syst. 79, 245-257 (2010).

42. Trouet, V., Taylor, A. H., Carleton, A. M. \& Skinner, C. N. Interannual variations in fire weather, fire extent, and synoptic-scale circulation patterns in northern California and Oregon. Theor. Appl. Climatol. 95, 349-360 (2009).

43. Lee, Y. Y. \& Grotjahn, R. Evidence of Specific MJO Phase Occurrence with Summertime California Central Valley Extreme Hot Weather. Adv. Atmos. Sci. 36, (2019).

44. Bayr, T., Domeisen, D. I. V. \& Wengel, C. The effect of the equatorial Pacific cold SST bias on simulated ENSO teleconnections to the North Pacific and California. Clim. Dyn. 53, 3771-3789 (2019).

45. Goodrich, G. B. Influence of the Pacific Decadal Oscillation on Winter Precipitation and Drought during Years of Neutral ENSO in the Western United States. Weather Forecast. (2007). doi:10.1175/waf983.1

46. Ropelewski, C. F. \& Halpert, M. S. North American Precipitation and Temperature Patterns Associated with the El Niño/Southern Oscillation (ENSO). Mon. Weather Rev. 114, 2352-2362 (2002).

47. Mills, C. M. \& Walsh, J. E. Seasonal variation and spatial patterns of the atmospheric component of the pacific decadal oscillation. J. Clim. (2013). doi:10.1175/JCLI-D-12-00264.1

48. Guirguis, K., Gershunov, A., Shulgina, T., Clemesha, R. E. S. \& Ralph, F. M. Atmospheric rivers impacting Northern California and their modulation by a variable climate. Clim. Dyn. 52, 6569-6583 (2019).

49. Luteyn, J. L. \& Hickman, J. C. The Jepson Manual: Higher Plants of California. Brittonia (1993). doi:10.2307/2807611

50. Western Regional Climate Center. (2020). Available at: https://wrcc.dri.edu/Climate/summaries.php.

51. He, M. \& Gautam, M. Variability and Trends in Precipitation, Temperature and Drought Indices in the State of California. Hydrology (2016). doi:10.3390/hydrology3020014

52. Meseguer-Ruiz, O. \& Sarricolea, P. Detección de inhomogeneidades en series de precipitación diaria en la región centro-sur de Chile. Interciencia 42, 242-249 (2017).

53. Gocic, M. \& Trajkovic, S. Analysis of changes in meteorological variables using Mann-Kendall and Sen's slope estimator statistical tests in Serbia. Glob. Planet. Change 100, 172-182 (2013).

54. Song, X. et al. Changes in precipitation extremes in the Beijing metropolitan area during 1960-2012. Atmos. Res. (2019). doi:10.1016/j.atmosres.2019.02.006

55. Kukal, M. \& Irmak, S. Long-term patterns of air temperatures, daily temperature range, precipitation, grassreference evapotranspiration and aridity index in the USA Great Plains: Part I. Spatial trends. J. Hydrol. (2016). doi:10.1016/j.jhydrol.2016.06.006

56. Sarricolea, P., Meseguer-Ruiz, Ó., Serrano-Notivoli, R., Soto, M. V. \& Martin-Vide, J. Trends of daily precipitation concentration in Central-Southern Chile. Atmos. Res. 215, 85-98 (2019).

Page 15/26 
57. Peña-Angulo, D. et al. Seasonal temperature trends on the Spanish mainland: A secular study (1916-2015). Int. J. Climatol. 41, (2021).

58. Liu, Q., Shepherd, B. \& Li, C. Presiduals: An R package for residual analysis using probability-scale residuals. J. Stat. Softw. 94, 1-27 (2020).

59. Hijmans, A. R. J., Phillips, S., Leathwick, J., Elith, J. \& Hijmans, M. R. J. Dismo: species distribution modeling. (2021).

60. Díaz-Padilla, G. et al. Mapeo del Índice de Aridez y su Distribución Poblacional en México. Rev. Chapingo Ser. Ciencias For. y del Ambient. XVII, 267-275 (2011).

61. Environmental Systems Research Institute (ESRI). ARCGIS. (2019).

62. Barber, X. et al. Bayesian hierarchical models for analysing the spatial distribution of bioclimatic indices. Sort 41, 277-296 (2017).

63. Gribov, A. \& Krivoruchko, K. Empirical Bayesian kriging implementation and usage. Sci. Total Environ. 722, (2020).

64. Krivoruchko, K. Empirical Bayesian Kriging. ESRI Press Fall 2012, 6-10 (2012).

65. Jiménez-Quiroz, C. Indicadores Climáticos. Una Manera para identificar la variabilidad climática a escala global. Inapesca (2014).

66. Ríos Cornejo, D., Penas, Á., Álvarez-Esteban, R. \& del Río, S. Links between teleconnection patterns and mean temperature in Spain. (2015).

67. Christy, J. R., Norris, W. B., Redmond, K. \& Gallo, K. P. Methodology and results of calculating central California surface temperature trends: Evidence of human-induced climate change? J. Clim. 19, (2006).

68. Niles, M. T. \& Mueller, N. D. Farmer perceptions of climate change: Associations with observed temperature and precipitation trends, irrigation, and climate beliefs. Glob. Environ. Chang. 39, 133-142 (2016).

69. Fassnacht, S. R. et al. Spatio-temporal snowmelt variability across the headwaters of the Southern Rocky Mountains. Front. Earth Sci. 11, 505-514 (2017).

70. Guarín, A. \& Taylor, A. H. Drought triggered tree mortality in mixed conifer forests in Yosemite National Park, California, USA. For. Ecol. Manage. (2005). doi:10.1016/j.foreco.2005.07.014

71. Hayhoe, K. et al. Sciences of the USA 12422-12427 PNAS. 101, (2004).

72. Pathak, T. B. et al. Climate change trends and impacts on California Agriculture: A detailed review. Agronomy 8 , (2018).

73. Williams, A. P. et al. Contribution of anthropogenic warming to California drought during 2012-2014. Geophys. Res. Lett. (2015). doi:10.1002/2015GL064924

74. Lebassi, B. et al. Observed 1970-2005 cooling of summer daytime temperatures in coastal California. J. Clim. 22, 3558-3573 (2009).

75. Weiss-Penzias, P. S. et al. Marine fog inputs appear to increase methylmercury bioaccumulation in a coastal terrestrial food web. Sci. Rep. 9, (2019).

76. Torregrosa, A., O’brien, T. A. \& Faloona, I. C. Coastal fog, climate change, and the environment. Eos 95, 473-474 (2014).

77. Johnstone, J. A. \& Dawson, T. E. Climatic context and ecological implications of summer fog decline in the coast redwood region. Proc. Natl. Acad. Sci. U. S. A. 107, 4533-4538 (2010).

78. Tamrazian, A., Ladochy, S., Willis, J. \& Patzert, W. C. Heat Waves in Southern California: Are They Becoming More Frequent and Longer Lasting? Yearbook of the Association of Pacific Coast Geographers 70, (2008). 
79. Basu, R., Rau, R., Pearson, D. \& Malig, B. Temperature and Term Low Birth Weight in California. Am. J. Epidemiol. 187, (2018).

80. The California Department of Water Resources. California Climate Science and Data: FOR WATER RESOURCES MANAGEMENT. (2015).

81. Kalnay, E., Cai, M., Li, H. \& Tobin, J. Estimation of the impact of land-surface forcings on temperature trends in eastern United States. J. Geophys. Res. Atmos. 111, (2006).

82. Diffenbaugh, N. S., Swain, D. L. \& Touma, D. Anthropogenic warming has increased drought risk in California. Proc. Natl. Acad. Sci. (2015). doi:10.1073/pnas.1422385112

83. Bellard, C., Bertelsmeier, C., Leadley, P., Thuiller, W. \& Courchamp, F. Impacts of climate change on the future of biodiversity. Ecology Letters (2012). doi:10.1111/j.1461-0248.2011.01736.x

84. Del Río González, S. El cambio climático y su influencia en la vegetación de Castilla y León (España). Itinera Geobot. 16, 5-534 (2005).

85. Peña-Gallardo, M., Gámiz-Fortis, S. R., Castro-Díez, Y. \& Esteban-Parra, M. J. Análisis comparativo de índices de sequía en andalucía para el periodo 1901-2012. Cuad. Investig. Geogr. (2016). doi:10.18172/cig.2946

86. Alfaro, E. et al. A method for prediction of california summer air surface temperature. Eos (Washington. DC). 85, (2004).

87. Liu, Y. C., Di, P., Chen, S. H. \& DaMassa, J. Relationships of rainy season precipitation and temperature to climate indices in California: Long-Term variability and extreme events. J. Clim. 31, (2018).

88. Allen, R. J. \& Luptowitz, R. El Niño-like teleconnection increases California precipitation in response to warming. Nat. Commun. 8, 1-15 (2017).

89. Zheng, C., Chang, E. K. M., Kim, H. M., Zhang, M. \& Wang, W. Impacts of the Madden-Julian oscillation on stormtrack activity, surface air temperature, and precipitation over North America. J. Clim. 31, (2018).

90. Wheeler, M. C. \& Hendon, H. H. An All-Season Real-Time Multivariate MJO Index: Development of an Index for Monitoring and Prediction. (2004).

91. Dasgupta, P., Metya, A., Naidu, C. V., Singh, M. \& Roxy, M. K. Exploring the long-term changes in the Madden Julian Oscillation using machine learning. Sci. Rep. 10, (2020).

\section{Figures}




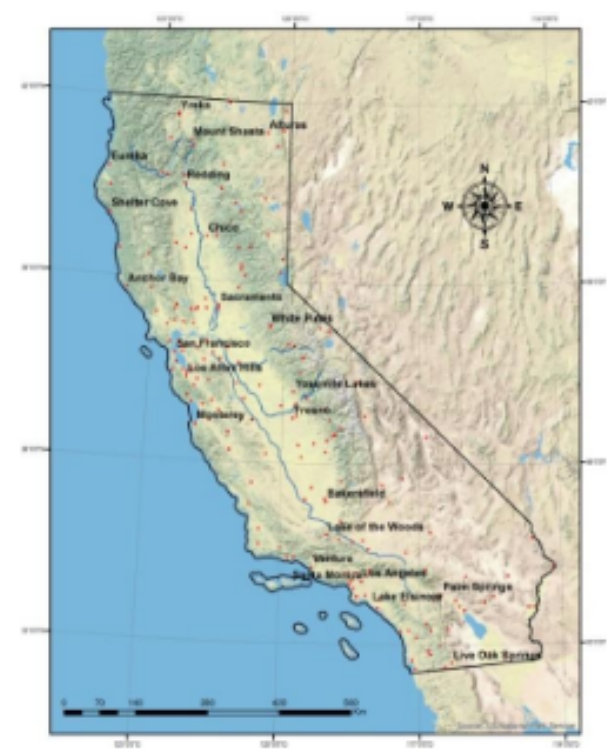

Figure. 1: Area of study and meteorological stations analysed ( $\bullet$ ).

Figure 1

See image above for figure legend.

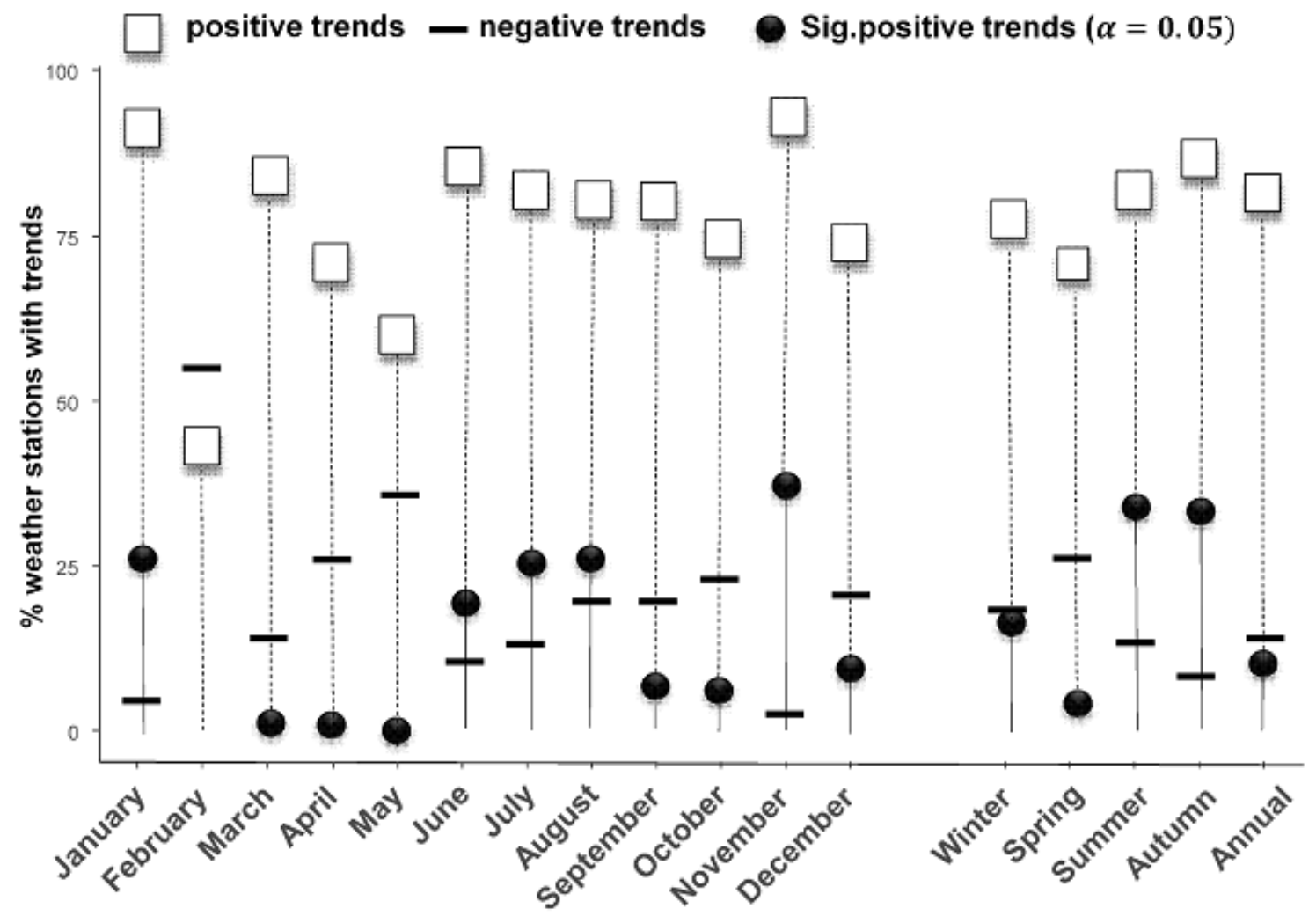

Figure 2

Percentages of weather stations with positive and negative trends 

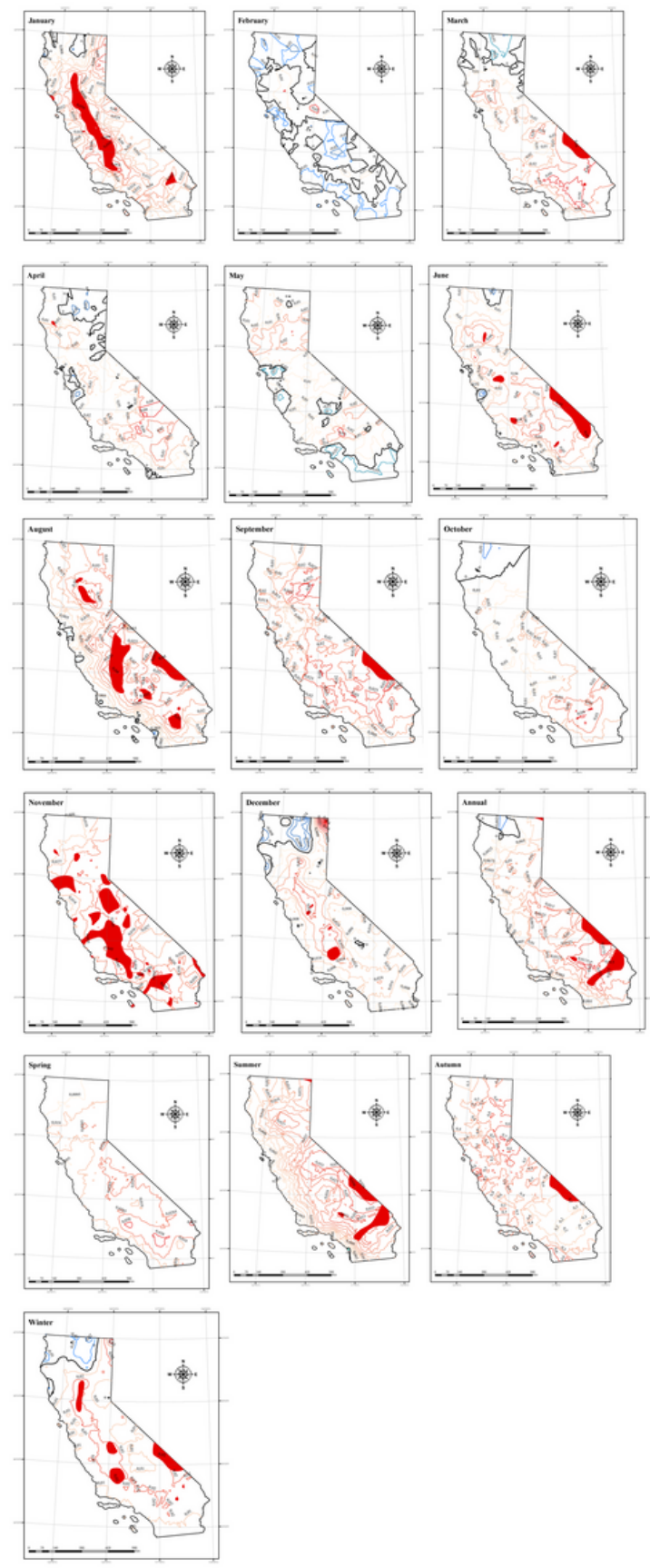

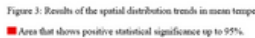

\section{Figure 3}

See image above for figure legend. 


\section{PDO. \% Significant teleconnection patterns}

January $9.3 \%$

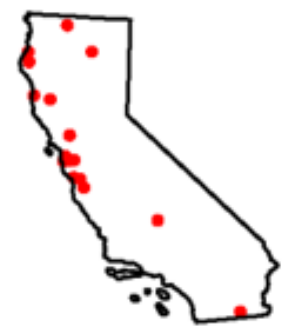

May $19.2 \%$

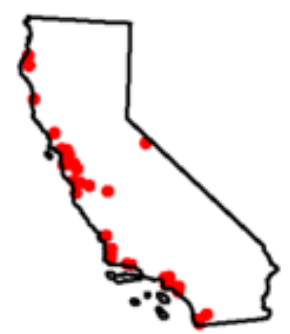

September $33.1 \%$

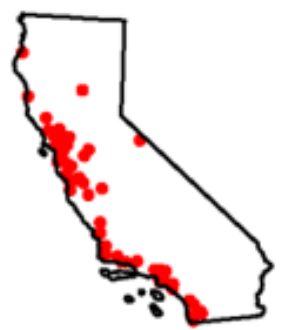

February $52.9 \%$

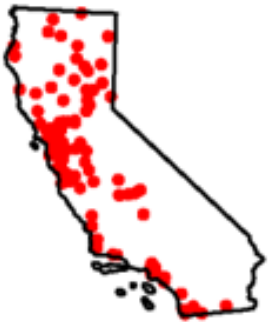

June $30.2 \%$

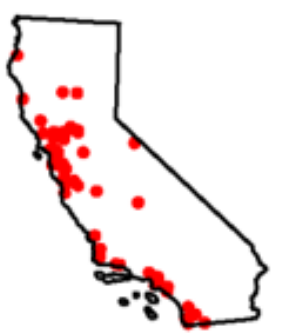

October $37.8 \%$

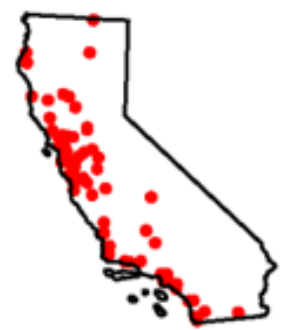

March $72.1 \%$

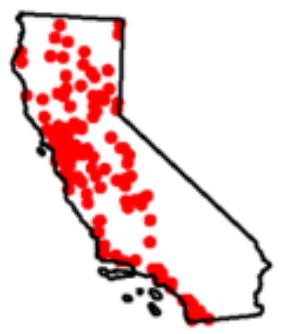

July $16.3 \%$

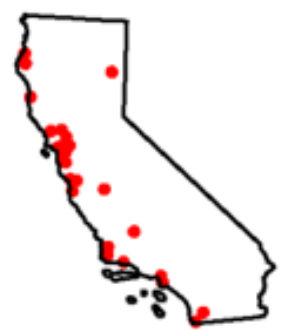

November $18.6 \%$

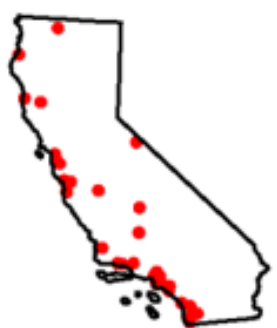

April $8.1 \%$

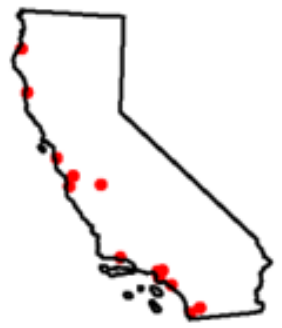

August $9.3 \%$

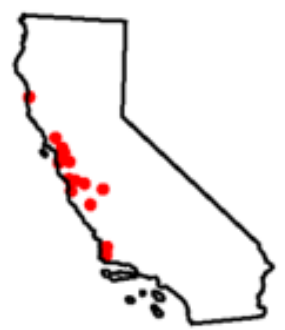

December $27.9 \%$

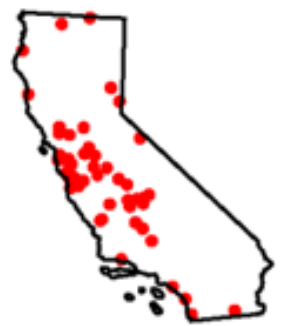

Figure 4

Percentage of California meteorology stations with significant correlations between PDO and temperature. 


\section{PNA. \% Significant teleconnection patterns}

January $20.3 \%$

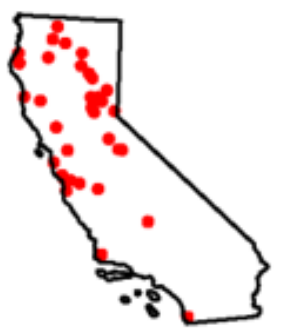

May $0.0 \%$

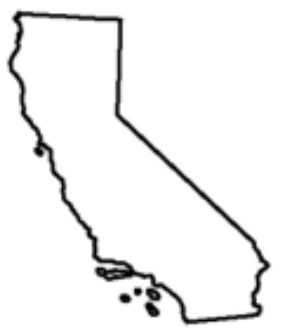

September $0.6 \%$

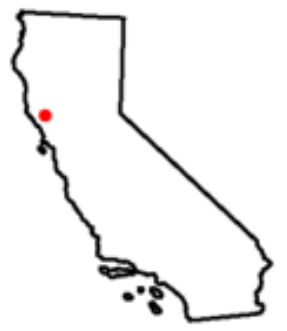

February $82.0 \%$

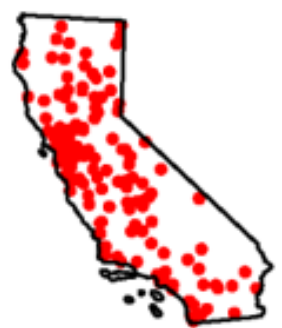

June $30.2 \%$

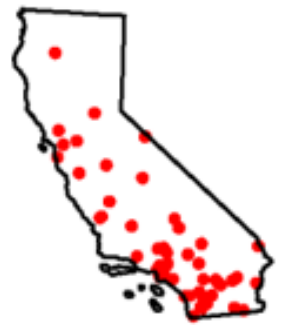

October $37.2 \%$

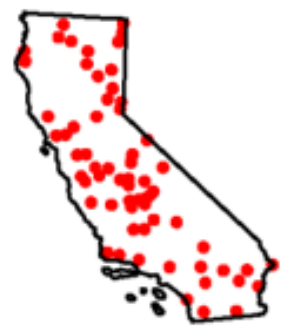

March $7.0 \%$

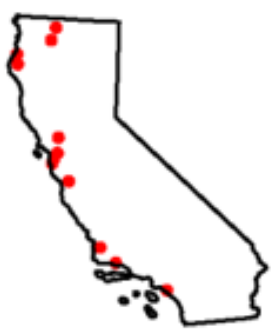

July $4.7 \%$

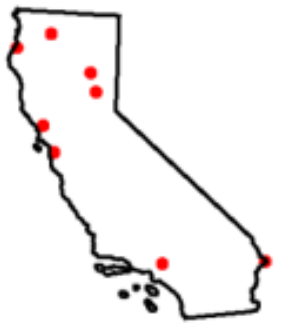

November $18.0 \%$

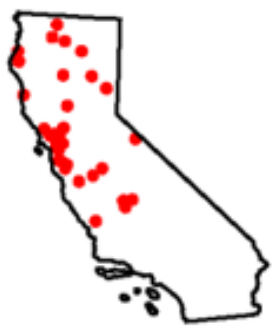

April $9.3 \%$

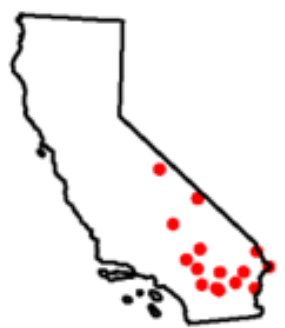

August $28.5 \%$

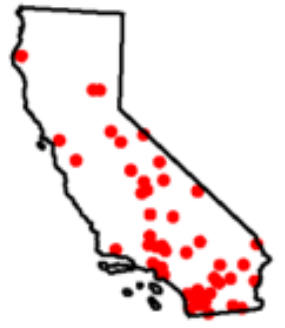

December $15.1 \%$

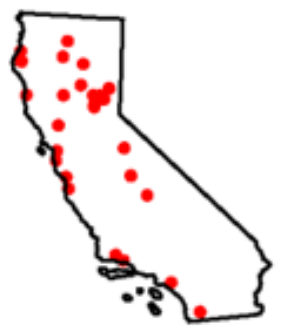

Figure 5

Percentage of California meteorology stations with significant correlations between PNA and temperature. 
WPO. \% Significant teleconnection patterns
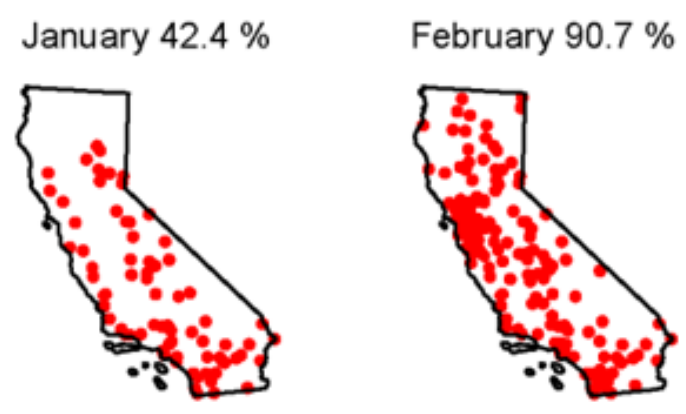

March $95.9 \%$

April $92.4 \%$

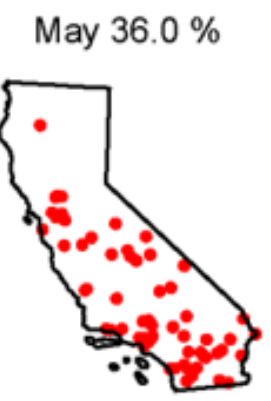

\begin{abstract}
June $8.1 \%$
\end{abstract}

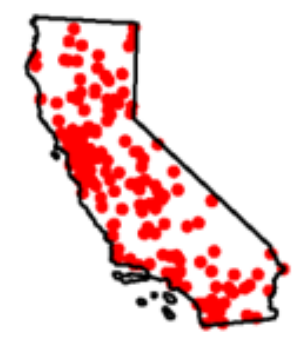

July $6.4 \%$
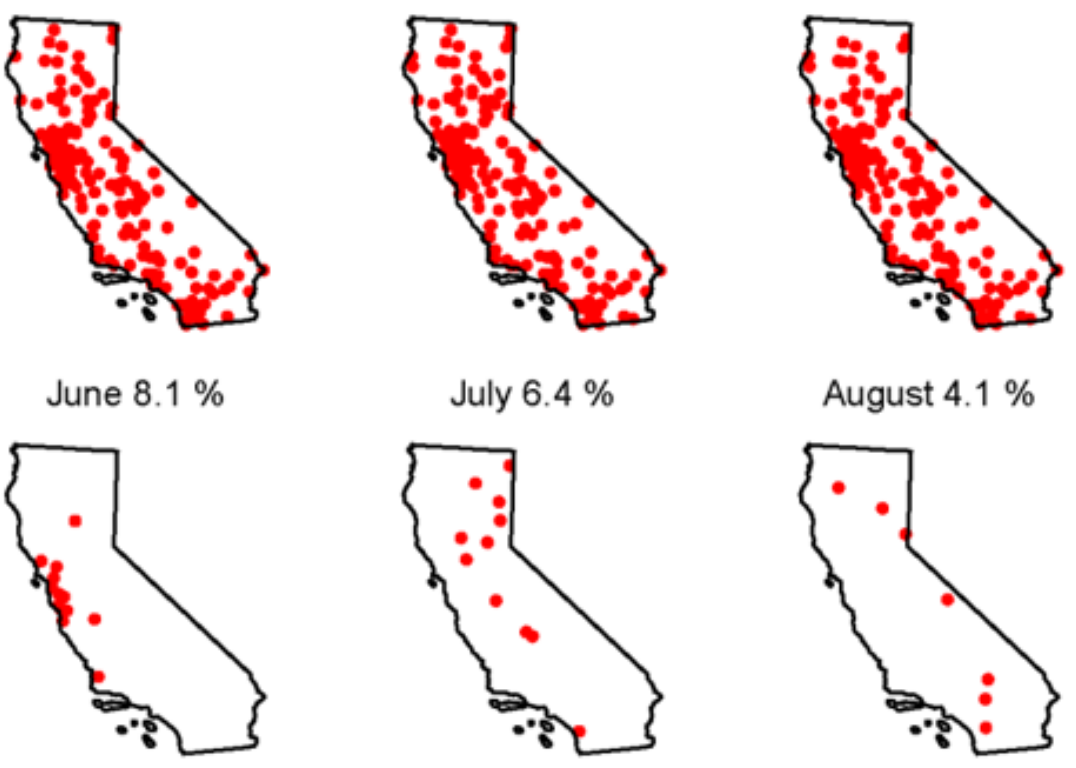

August $4.1 \%$

September $8.1 \%$

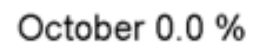

November $15.1 \%$
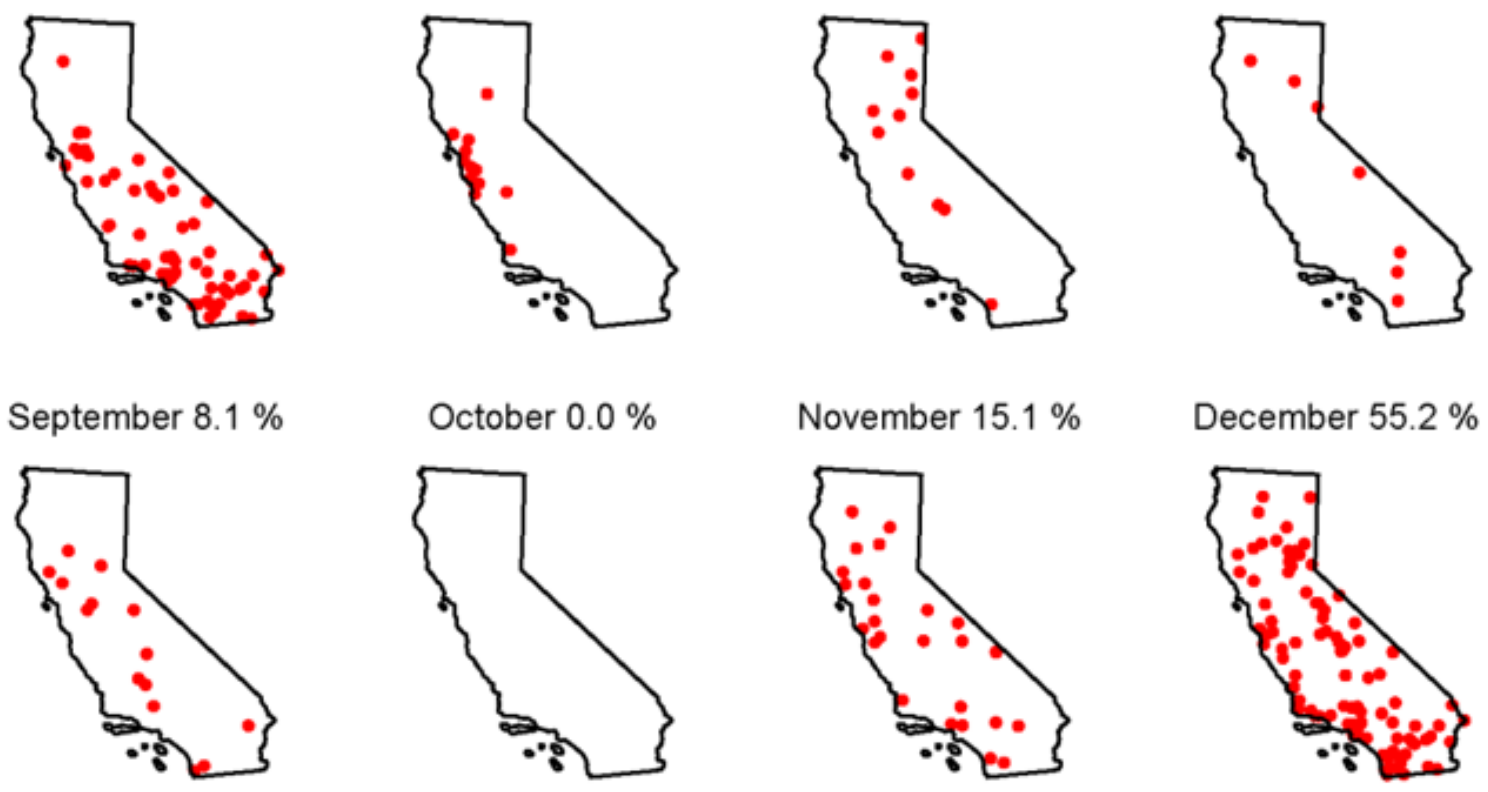

December $55.2 \%$

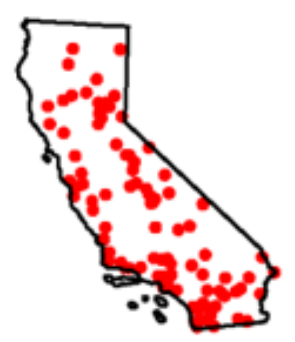

Figure 6

Percentage of California meteorology stations with significant correlations between WPO and temperature. 
EPO. \% Significant teleconnection patterns
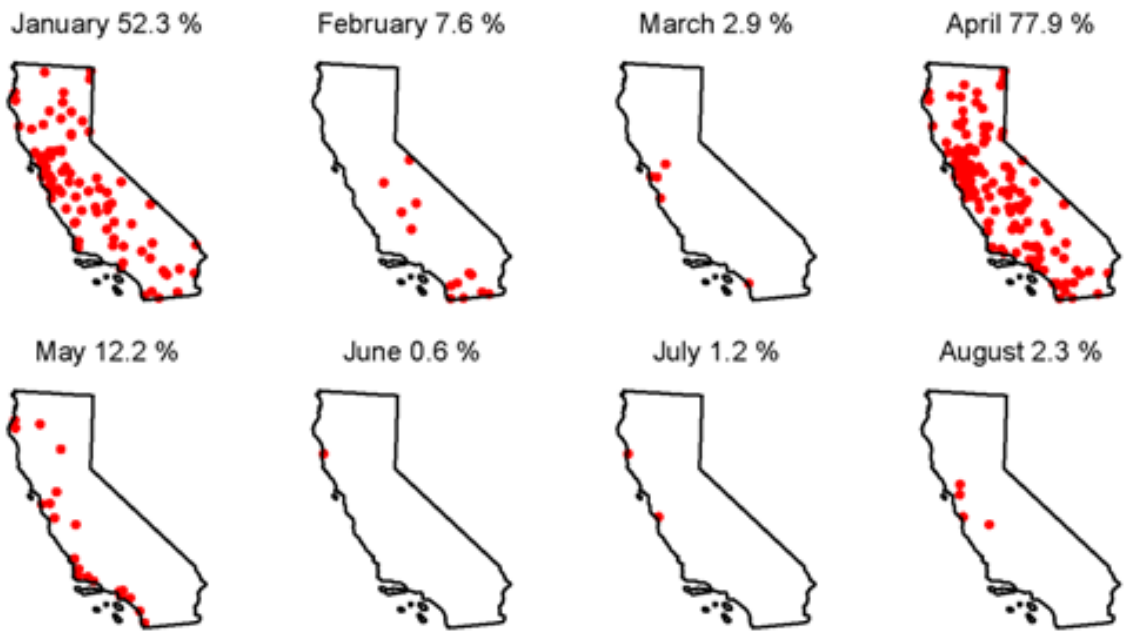

August $2.3 \%$

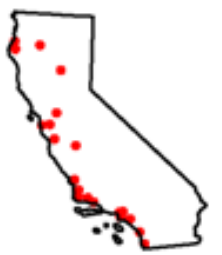

October $30.2 \%$

November $57.0 \%$

September $1.7 \%$
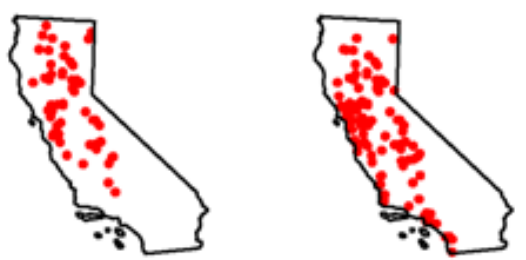

Figure 7

Percentage of California meteorology stations with significant correlations between EPO and temperature.

NAO. \% Significant teleconnection patterns
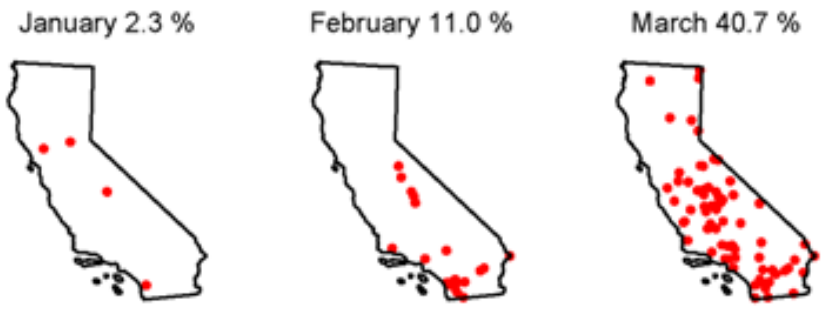

April $88.4 \%$

May $56.4 \%$

June $8.7 \%$

July $48.3 \%$
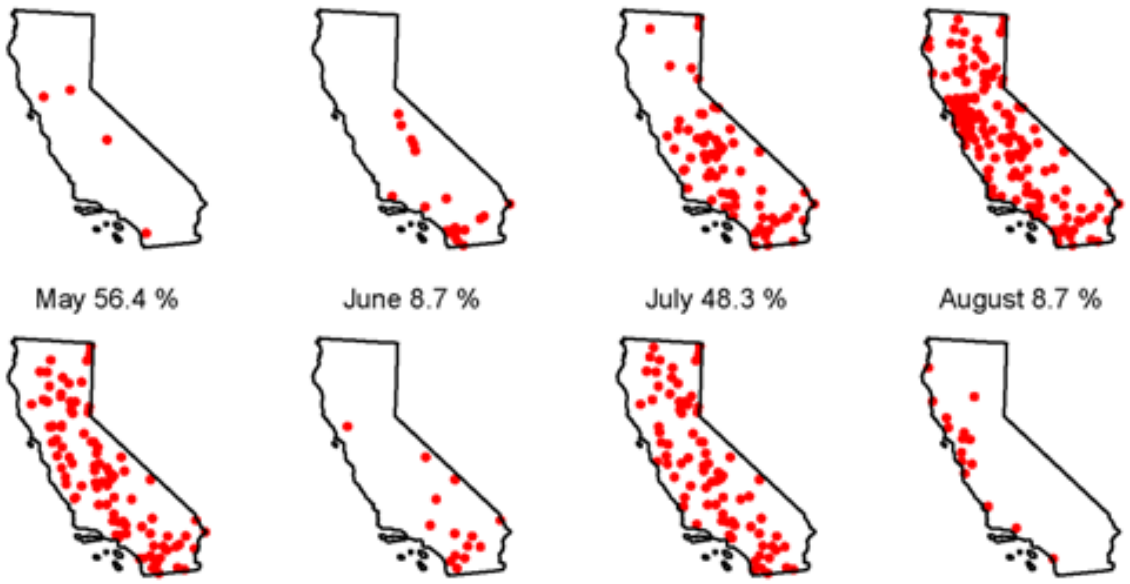

August $8.7 \%$

September $0.0 \%$

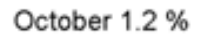

November $9.3 \%$
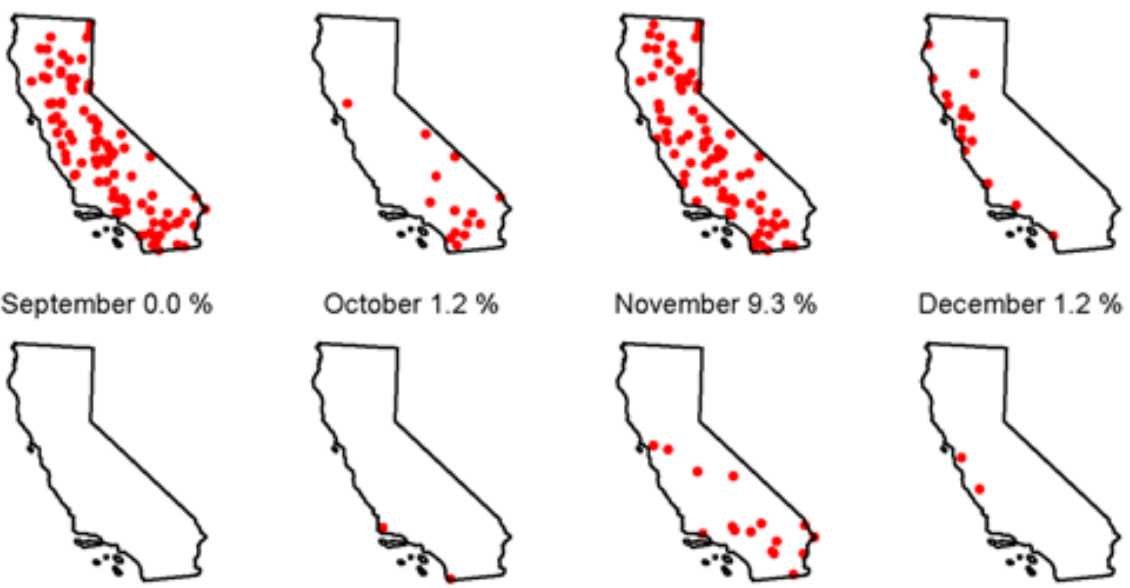

December $1.2 \%$

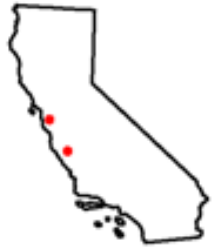


Figure 8

Percentage of California meteorology stations with significant correlations between NAO and temperature.

ENSO. \% Significant teleconnection patterns
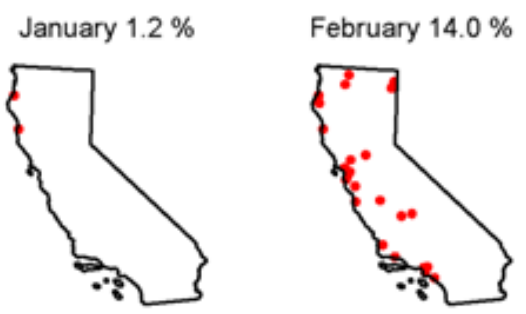

March $15.1 \%$

April $1.7 \%$

May $2.9 \%$

June $0.0 \%$
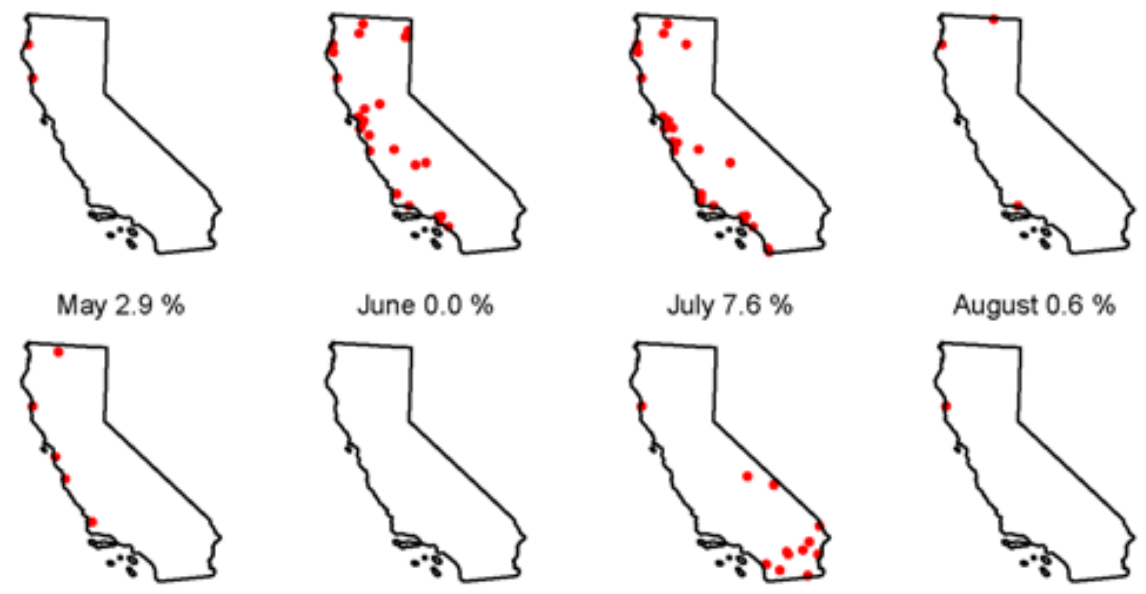

August $0.6 \%$

September $4.7 \%$

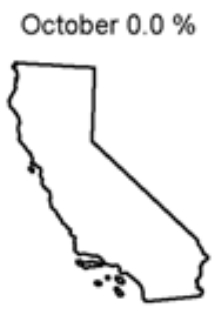

November $1.7 \%$
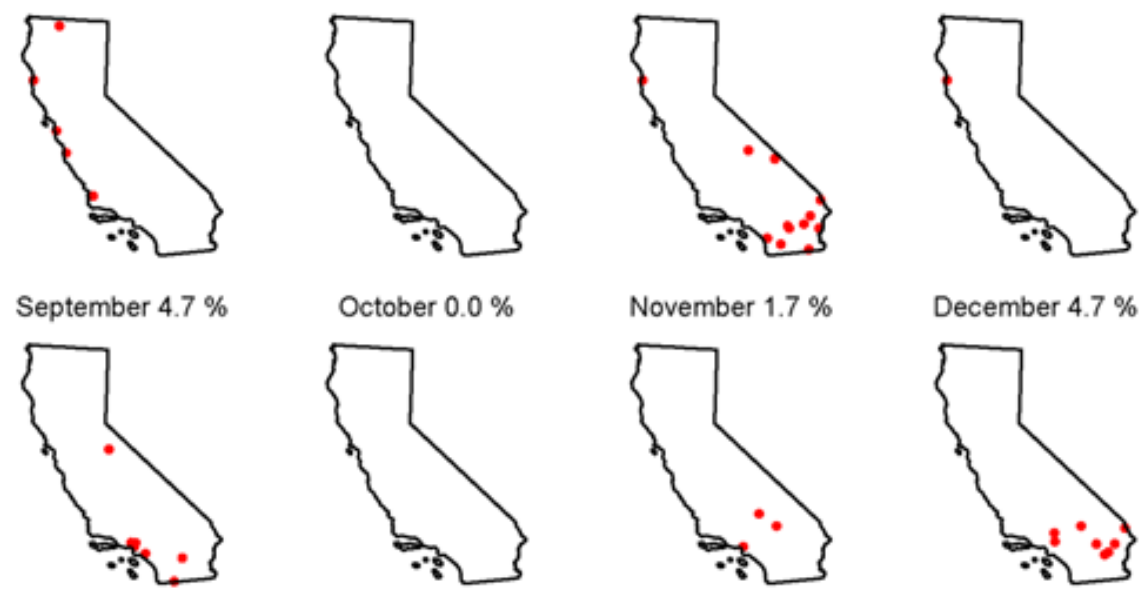

December $4.7 \%$

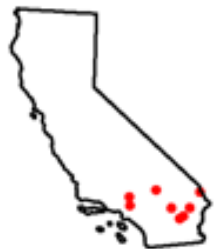

Figure 9

Percentage of California meteorology stations with significant correlations between ENSO and temperature. 
RMM1. \% Significant teleconnection patterns
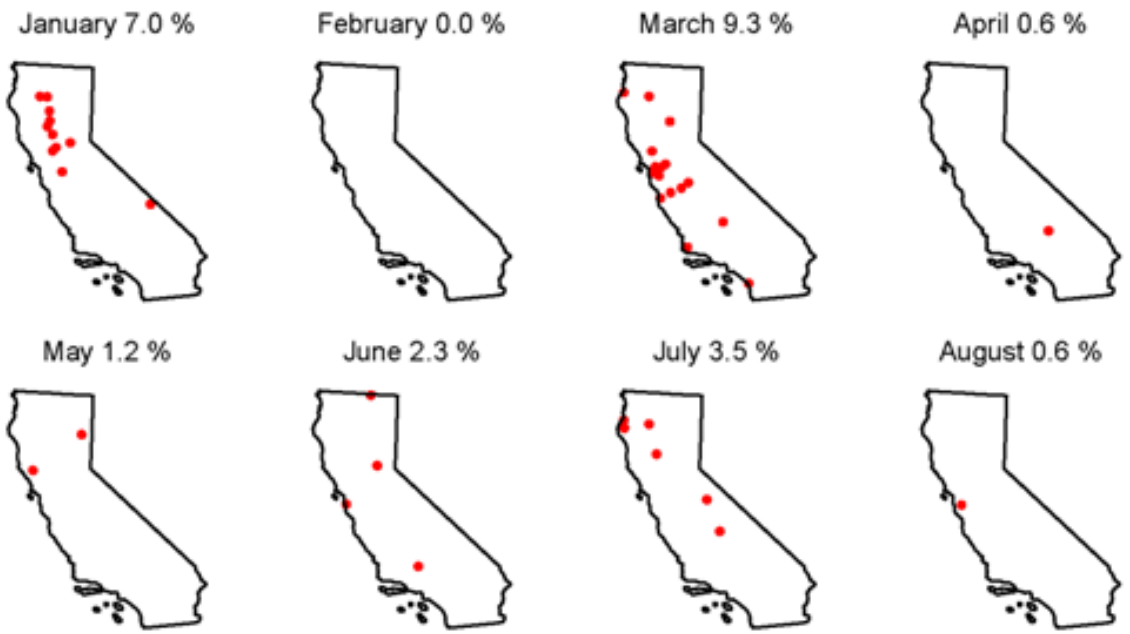

August $0.6 \%$

September $4.7 \%$

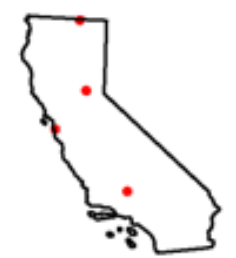

November $0.0 \%$
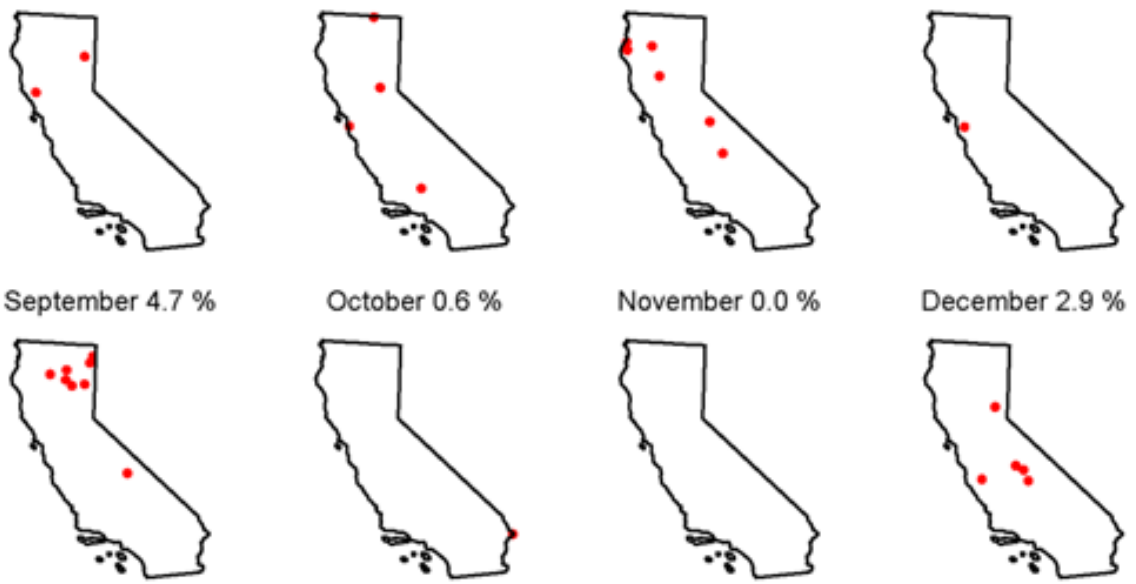

Figure 10

Percentage of California meteorology stations with significant correlations between RMM1 index of MJO and temperature. 
RMM2. \% Significant teleconnection patterns
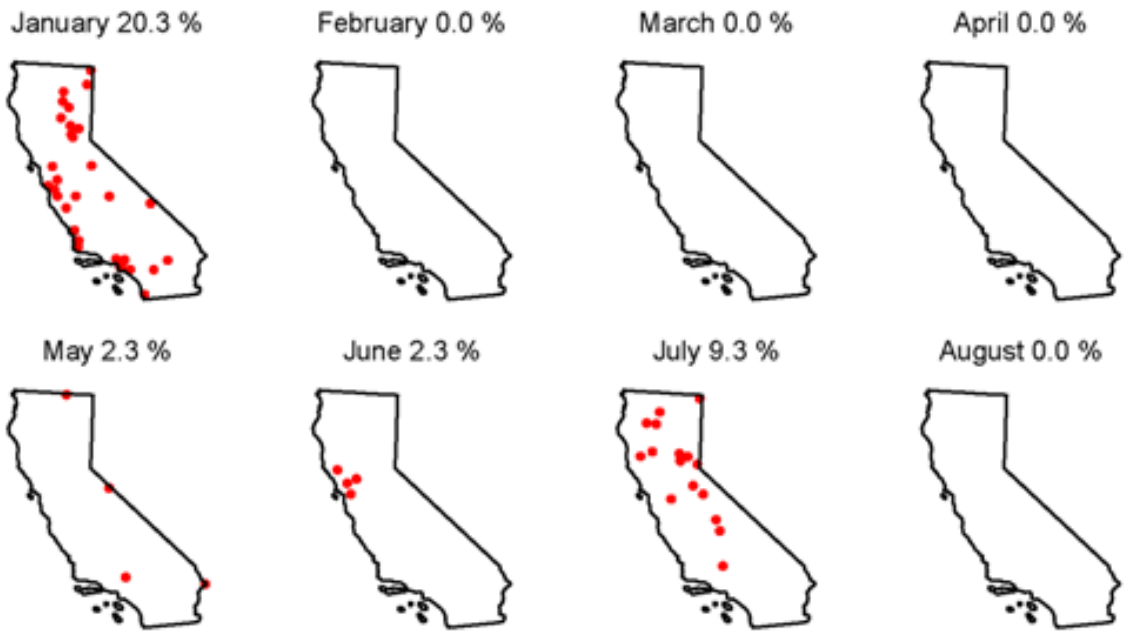

September $0.0 \%$

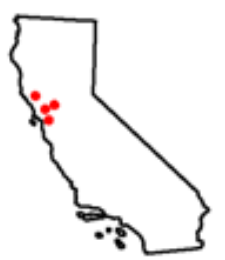

November $41.3 \%$

December $0.0 \%$
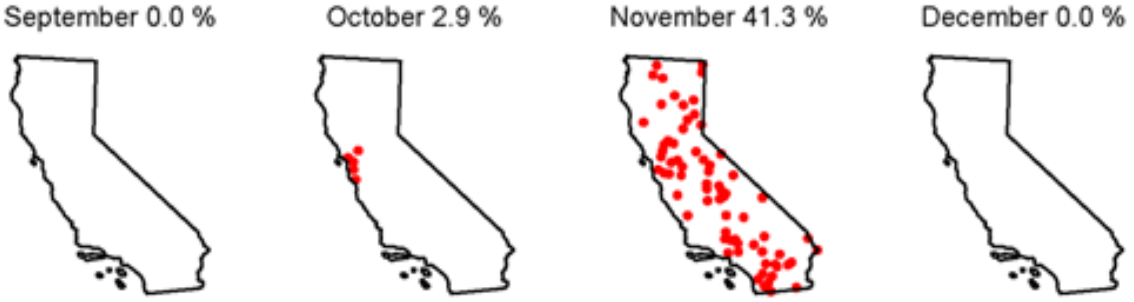

Figure 11

Percentage of California meteorology stations with significant correlations between RMM2 index of MJO and temperature.

\section{Supplementary Files}

This is a list of supplementary files associated with this preprint. Click to download.

- SuplementaryMaterial.docx 